of milk (including a chapter on immunological aspects of colostrum). Though one or two of the individual chapters are a little discursive, all are a pleasure to read and of engrossing interest to any advanced student of mammalian (including human) physiology or biochemistry. Excellent author- and subjectindexes are provided.

The volumes, if a little expensive for British pockets, are very well produced and adequately illustrated; no library concerned with physiology or biochemistry, with human or veterinary medicine or with dairy science can spend 186s. to better advantage than by their purchase.

H. D. KAY

\section{QUEST FOR NATURAL LAWS IN PLANT ECOLOGY}

Introduction to Plant Ecology

By Dr. Maurico Ashby. Pp. vii +249 . (London : Macmillan and Co., Ltd. ; New York : St. Martin's Press, Inc., 1961.) 25s. net.

The Plant Community

By Prof. Herbert C. Hanson and Ethan D. Churchill. Pp. xii +218. (New York: Reinhold Publishing Corporation; London : Chapman and Hall, Ltd., 1961.) 40s, net.

TTHE science of plant ecology is growing slowly out of its oarly descriptive phases and is becoming analytical and tentatively synthetic. It is no overstatement to say that the contribution of the present and next generation of ecologists may well be the establishment of principles analogous to those governing Newtonian physies or genetics.

Dr. Ashby's book, confessedly not new, is aimed to give pupils in sehool sixth forms and first-year university undergraduates a synopsis of these current aspects of plant ecology. He stresses the actual natural situations and the reactions of plants to them, making autecology the basis of his approach, using nine out of eleven chapters to develop a review of soils (thoroughly), root systems in relation to soil, effects of light, temperature and water on shoots, and biotic factors. He follows on with a study of "aggression", analysing factors concerned in spread and dispersal of species. One chapter is devoted to the nature of plant communities, succession and climaxes. A useful chapter and an appendix covor aims and methods of studying vegetation. A bibliography is provided.

The book is fairly well produced, having regard to its price, and contains lucid figures and some photographs. Even when price and costs are borne in mind, English text-books are not generally as attractivo as American ones : an important point is arousing interest in schools. One has but to see how sixth-form pupils become absorbed in American books to appreciate the advances needed in book production elsewhere.

Dr. Ashby has trodden in the footsteps of the Pasteur of British ecology-the late Sir Arthur Tansley and has woven into his work some of the modern developments of the topics Tansley the pioneer delineatod. Thus we find chemistry, statistios and factorial interactions rightly stressed.

It is no fault of Dr. Ashby's or the American authors that plant ecology has become tainted with a most infortunate form of anthropomorphism in the nse of words like 'tolerance', 'sociability', 'fidelity', 'aggression', 'peaceful relations' and 'competition'. I'erhaps the trend began with Darwin's use of the phrase 'struggle for existence'. Do we really have evidence of a plant psychology? Do we really have evidence that seedlings can act 'aggressively' (that is, launch an unprovoked attack)? Or are we as scientists so poor in vocabulary that we are unable to choose (or adapt classical) suitable words to express the interaction of physico-chemical systems concerned in given situations, for example, climate, soil and organism? Perhaps it is too late for ecologists to change their terminology; but the International Botanical Congress at Edinburgh in 1963 may find it possible to examine this unfortunate nomenclature.

Prof. Hanson and Mr. Churchill set out from a different starting point from Dr. Ashby's. They aim to supplement an elementary course by approach. ing the study of plant communities analytically and synthetically: a synecological study. Thus more than half thoir beautifully produced American book is concerned with the factorial interactions which influence groupings of species. It is not derogatory to suggest that in this liberally illustrated work, with many good photographs and tabulated information, some diagrams could have been more lucid than they are.

It is in the fourth part of tho book that one glimpses the new synthetic approach to the classification of plant communities ('synsystematics'). Here are set out the inklings of the new principles, such as the predictive value of the presence of a given species, acting not merely as an indicator, say, of soil-type, but also as an index to the other species that will occur in the community. This book might well find a place on the shelves of school and university libraries to give reading matter to follow up an elementary course.

At a time of grave responsibility for agriculturists in the feeding of the world, the more an understaning of ecological principles and their application there is, the better for us all. Both books contribute to this end in different ways. L. M. J. Kramer

\section{MORPHOGENESIS}

\section{Advances in Morphogenesis}

Vol. 1. Edited by M. Abercrombie and Jean Brachet. Pp. xiii + 445. (New York: Academic Press, Inc.; London: Academic Press, Inc. (London), Ltd., 1961.) 89s. $6 d$.

TVESTIGATIONS over the past thirty years or so have, for all practical purposes, converted the embryologist into a morphogeneticist. Embryology. sensuo stricto, has grown enormously; some allied kinds of investigations, such as in regeneration, now form a respectable part of it. The subject has also spread into intcresting and valuable contact with other biological endcavours; one recalls the influonce on the subject by studies in, for example, many aspects of cell biology, such as in genetics, in protein synthesis, on micro-organisms, in immunology, etc. The erstwhile embryologist now not only has his finger in a pretty big pie of his own, but also has a hungry cye focused on the pios of many others. Such gluttony is exciting, but it brings problems in its trail; more and more does it become difficult to see the main themes of the meal or even indeed to partake of it all.

In Advances in Morphogenesis the editors aro making an encouraging and timely attempt to meet this situation. Their conception of morphogenesis is rightly a wide one ".."any study of the new formation 